\title{
The Relationship of Interleukin-8 Levels in Children's Gastritis with and without Helicobacter Pylori Infections Maria $^{\mathrm{a}}$, Supriatmo , Oke Rina Ramayanic ${ }^{\mathrm{c}}$ Isti Ilmiati Fujiatid, Guslihan Dasa Tjiptae ${ }^{\mathrm{e}}$ Rina Amalia C Saragih ${ }^{\mathrm{f}}$
}

${ }^{a}$ harukomagic@gmail.com

${ }^{a}$ Resident of Paediatrics, Medical School, Universitas Sumatera Utara/ Adam Malik Hospital, Medan, Indonesia

${ }^{b}$ Department of Paediatric, Medical School, Universitas Sumatera Utara/ Adam Malik Hospital, Medan, Indonesia

${ }^{c}$ Department of Paediatrics, Medical School, Universitas Sumatera Utara/ Adam Malik Hospital, Medan, Indonesia

${ }^{d}$ Department of Community Medicine, Medical School, Universitas Sumatera Utara/ Adam Malik Hospital, Medan, Indonesia

${ }^{e}$ Department of Paediatric, Medical School, Universitas Sumatera Utara/ Adam Malik Hospital, Medan, Indonesia

${ }^{f}$ Department of Paediatrics, Medical School, Universitas Sumatera Utara/ Adam Malik Hospital, Medan, Indonesia

\begin{abstract}
Background: Gastritis is a gastrointestinal health problem that often occurs and is divided into acute and chronic gastritis. Where the main cause of chronic gastritis is Helicobacter pylori infection. The number of Interleukin-8 (IL-8) expressed by gaster epithelial cells in response to Helicobacter pylori is sufficient to induce neutrophil chemotaxis, which is associated with a variety of gastrointestinal diseases including gastritis, peptic ulcer cells, gaster carcinoma and gastric mucosa sufficient to induce neutrophil chemotaxis, which is associated with various gastrointestinal diseases including gastritis, peptic ulcer cells, gastric carcinoma and gastric mucosa sufficient to induce neutrophil chemotaxis, which is associated with various gastrointestinal diseases including gastritis, peptic ulcer cells, gastric carcinoma and gastric mucosa-associated lymphoid-tissue lymphoma. Objective: To analysis the relationship of IL-8 levels in pediatric gastritis with and without Helicobacter pylori infection. Method: A cross sectional study was conducted In outpatient and inpatient department in three centers from March until April 2020. The diagnosis of Helicobacter pylori gastritis was confirmed by CLO test. Blood sample was taken from subjects to evaluate interleukin- 8 level. Result: 60 subjects with gastrointestinal complaints were reviewed. Subjects were divided into 2 groups based on CLO test, 29 subjects with Helicobacter pylori infection and 31 subjects without Helicobacter pylori infection. From the analysis, mean IL-8 value was $25,86 \mathrm{pg} / \mu \mathrm{l}$ and $10,99 \mathrm{pg} / \mu \mathrm{l}$ in helicobacter and non-helicobacter group respectively $(\mathrm{p}<0,001)$. Conclusion: There are differences levels of IL- 8 value between Helicobacter pylori gastritis and non Helicobacter pylori gastritis in children.
\end{abstract}

Keyword: gastritis, Helicobacter pylori, interleukin-8

\section{Introduction}

Gastritis is one of the most common gastrointestinal health problems. Gastritis can be divided into acute gastritis and chronic gastritis. Most children with chronic gastritis have secondary inflammation or mucosal ulcers. The leading cause of chronic gastritis is H. Pylori bacterial infection. H. Pylori infection is associated with various gastrointestinal diseases, including gastritis, peptic ulcers, gastric carcinoma, and gastric mucosaassociated lymphoid tissue lymphoma. ${ }^{1,2} \mathrm{H}$. pylori can cause gastritis in infected children with non-specific clinical manifestations. ${ }^{2}$ In developing countries, the prevalence of $\mathrm{H}$. pylori infection in children under 10 years is about $80 \%$, while in developed countries, it is about $10 \% .^{2,3}$

H. Pylori infection causes gastric mucosal inflammation so that the gastric epithelium releases interleukin$1 \beta$, interleukin-2, interleukin-6, interleukin-8, and tumor necrosis factor- $\alpha$. Interleukin- 8 or Human Neutrophil Activating Factor (NAF-1) is the most important neutrophil-activating chemokine expressed in gastric epithelial cells associated with the recruitment of neutrophils toxic metabolites and lysosomal enzymes are released neutrophils creates gastric mucosal damage ${ }^{4-6} \mathrm{H}$. pylori trigger systemic and local humoral responses that produce antibodies. These antibodies do not function to clear pathogens but instead cause tissue damage by destroying the $\mathrm{H}+/ \mathrm{K}+-$ ATPase parietal cells that produce gastric acid, causing corpus atrophy achlorhydria conditions..$^{7-9}$

Research on the relationship of IL-8 level expression between gastritis patients with or without H. Pylori infection at H. Adam Malik Hospital, University of North Sumatera Hospital, and Satellite Education Hospital but still no interleukin-8 level difference noted. So, the author wants to study the interleukin-8 level 
differences in gastritis patients with H. pylori and without H. pylori.

\section{Method}

Our cross sectional analytic study was conducted at Gastroenterology Policlinic and Ward in H. Adam Malik Medan Hospital, Universitas Sumatera Utara Hospital, and Satellite Education Hospital Medan in March - April 2020 after obtaining ethical clearance from Universitas Sumatera Utara, with inclusion criteria: children $2-18$ years old with suspected gastritis or diagnosed with gastritis and willing to join and agree to follow our study procedures. Patients using proton pump inhibitor (PPI), H2 receptor antagonist, antibiotic or non-steroid anti-inflammatory drugs (NSAID) within 14 days, malignancy, immunosuppression disease, gastric bleeding, patients with a history of gastric operation, and history with other infection that not related to gastritis infection are excluded. The subject appropriate with inclusion criteria will be noted, perform HpSA test, urea breath test or campylobacter like organism (CLO) test and interleukin-8 in standardized laboratory. All the data will noted and analysed statistically by using SPSS version 23 with descriptive study, comparison of unpaired group with T-test and if distributed unnormal the data will be analyse with Mann Whitney test. Data normality will use Saphiro Wilk test. The significance of the statistical test results was determined based on a $\mathrm{P}$ value $<0.05$ with a $95 \%$ confidence interval. (figure 1 )

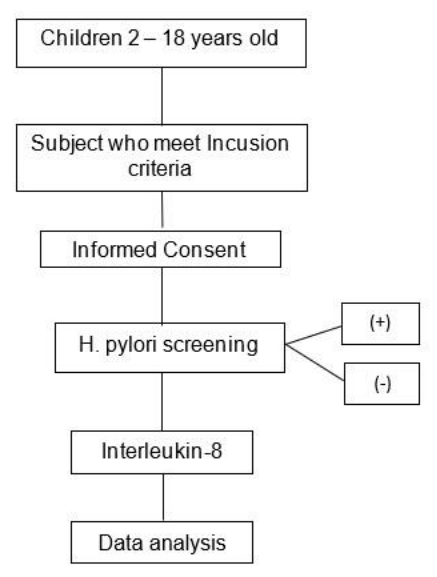

Figure 1. Subject recruitment

\section{Result}

Our study was followed by 60 children with gastritis symptoms who met the inclusion and exclusion criteria. Endoscopic examination results showed 29 children with positive H. pylori and 31 children with negative $\mathrm{H}$. pylori. Our study found female $60 \%$ with mean age 11,57 years old, youngest 2,8 years old and oldest 17,5 years old. Mean body weight 36,42 years old and mean body length 136,6 years old. We found Bataknese was the most in ethnic group, majority of children education level primary and secondary school. Majority of parent's educational level and occupation were college and entrepreneur. Most cases with good socioeconomic status $88,3 \%$, family history $44,7 \%$, and abdominal pain $56,7 \%$ (table 1 ). 


\begin{tabular}{|c|c|c|}
\hline Subject Characteristic & $n=60$ & \\
\hline \multicolumn{3}{|l|}{ Gender, n (\%) } \\
\hline Male & $24(40)$ & \\
\hline Female & $36(60)$ & \\
\hline \multicolumn{3}{|l|}{ Age, n (\%) } \\
\hline Mean & 11,57 & \\
\hline Median & 12,6 & \\
\hline SD & 3,58 & \\
\hline Min Max & $2,8-17,5$ & \\
\hline \multicolumn{3}{|l|}{ Body Weight, mean (SD), kg } \\
\hline Mean & 36,42 & \\
\hline Median & 35 & \\
\hline SD & 11,72 & \\
\hline Min Max & $9-60$ & \\
\hline \multicolumn{3}{|l|}{ Body Height, mean (SD), cm } \\
\hline Mean & 136,6 & \\
\hline Median & 141,5 & \\
\hline SD & 18,52 & \\
\hline Min Max & $84-167$ & \\
\hline \multicolumn{3}{|l|}{ Ethcnic Group, n (\%) } \\
\hline Acehnese & $8(13,3)$ & \\
\hline Bataknese & $25(41,7)$ & \\
\hline Indianese & $1(1,7)$ & \\
\hline Javanese & $7(11,7)$ & \\
\hline Melayunese & $9(15)$ & \\
\hline Minangnese & $7(11,7)$ & \\
\hline Papuanese & $2(3,3)$ & \\
\hline Chineese & $1(1,7)$ & \\
\hline \multicolumn{3}{|l|}{ Child educational level, n (\%) } \\
\hline Kindergarten & $4(6,7)$ & \\
\hline Primary school & $21(35)$ & \\
\hline Secondary school & $21(35)$ & \\
\hline Senior high school & $10(16,7)$ & \\
\hline College & $4(6,7)$ & \\
\hline \multicolumn{3}{|l|}{ Father educational level, n (\%) } \\
\hline Senior high school & $12(20)$ & \\
\hline College & $48(80)$ & \\
\hline \multicolumn{3}{|l|}{ Mother educational level, $\mathrm{n}(\%)$} \\
\hline Senior high school & $4(6,7)$ & \\
\hline College & $56(93,3)$ & \\
\hline \multicolumn{3}{|l|}{ Father's occupation, n (\%) } \\
\hline Private employee & $32(53,3)$ & \\
\hline Farmer & $3(5)$ & \\
\hline Government employee & $6(10)$ & \\
\hline Army/police & $3(5)$ & \\
\hline Enterpreneur & $16(26,7)$ & \\
\hline \multicolumn{3}{|l|}{ Mother's occupation, n (\%) } \\
\hline Private employee & $22(36,7)$ & \\
\hline Farmer & $5(8,3)$ & \\
\hline Government employee & $11(18,3)$ & \\
\hline Enterpreneur & $13(21,7)$ & \\
\hline Housewife & $9(15)$ & \\
\hline \multicolumn{3}{|l|}{ Sosioeconomic status, n (\%) } \\
\hline Scant & $7(11,7)$ & \\
\hline \multirow{2}{*}{\multicolumn{3}{|c|}{ Clinical manifestation, $\mathrm{n}(\%)$}} \\
\hline & & \\
\hline Nausea & $3(5)$ & \\
\hline Vomitus & $11(18,3)$ & \\
\hline Haematemesis & $12(20)$ & \\
\hline Abdominal pain & $34(56,7)$ & \\
\hline \multicolumn{3}{|l|}{ Family history, n (\%) } \\
\hline Yes & $40(44,7)$ & \\
\hline No & $20(33,3)$ & \\
\hline
\end{tabular}

Table 1. Subject characteristic

We analyze the data that show in table 2 . We found female greater both in positive and negative H. pylori with $62,1 \%$ and $58,1 \%$. We perform Chi square test and found no significant proportion different in gender group ( $\mathrm{p}=0,752$ ). Mean age in positive $\mathrm{H}$. pylori group 11,35 years old while negative $\mathrm{H}$. pylori 11,78 years old and when we perform Mann-Whitney test we also found no significant different in mean age with $\mathrm{H}$. pylori ( $\mathrm{p}=0,706)$. In ethnic group we found Bataknese was the greatest among other with $41,4 \%$ in positive $\mathrm{H}$. 
pylori and 41,9\% in negative H. pylori. We performed Kruskal Wallis and found no significant different in ethnic group ( $\mathrm{p}=0,744)$. Good socieconomic status found higher both in two groups with $89,7 \%$ in positive $\mathrm{H}$. pylori and $87,1 \%$ in negative $H$. pylori, and when we analyze with Fischer's exact test we found no significant difference between two groups $(\mathrm{p}=1,000)$. The highest level of children's education in the two groups was secondary school $37,9 \%$ in positive $\mathrm{H}$. pylori and $35,5 \%$ primary school in negative $\mathrm{H}$. pylori. We found no significant difference in children's educational level both in the two study groups $(\mathrm{p}=0.981)$ after analyzed with Kruskal Wallis test.

\begin{tabular}{|c|c|c|c|}
\hline \multirow[b]{2}{*}{ Subject Characteristic } & \multicolumn{2}{|c|}{ H. pylori } & \multirow[b]{2}{*}{$\mathrm{p}$} \\
\hline & $\begin{array}{c}\text { Positive } \\
n=29\end{array}$ & $\begin{array}{c}\text { Negative } \\
\mathbf{n = 3 1}\end{array}$ & \\
\hline \multicolumn{4}{|l|}{$\overline{\text { Gender, n (\%) }}$} \\
\hline Male & $11(37,9)$ & $13(41,9)$ & \multirow[t]{2}{*}{$0,752^{a}$} \\
\hline Female & $18(62,1)$ & $18(58,1)$ & \\
\hline Age, n (\%), Mean (SD), years & $11,35(3,81)$ & $11,78(3,41)$ & $0,706^{\circ}$ \\
\hline Body weight, $\mathrm{n}(\%)$, Mean (SD), kg & $36,38(13,96)$ & $36,47(9,39)$ & $0,977^{\mathrm{c}}$ \\
\hline \multicolumn{4}{|l|}{ Ethcnic Group, $\mathrm{n}(\%)$} \\
\hline Acehnese & $4(13,8)$ & $4(12,9)$ & \multirow[t]{8}{*}{$0,744^{\circ}$} \\
\hline Bataknese & $12(41,4)$ & $13(41,9)$ & \\
\hline Indianese & $1(3,4)$ & $0(0)$ & \\
\hline Javanese & $3(10,3)$ & $4(12,9)$ & \\
\hline Melayunese & $4(13,8)$ & $5(16,1)$ & \\
\hline Minangnese & $3(10,3)$ & $4(12,9)$ & \\
\hline Papuanese & $2(6,9)$ & 0 & \\
\hline Chineese & 0 & $1(3,2)$ & \\
\hline \multicolumn{4}{|l|}{ Sosioeconomic status, n (\%) } \\
\hline Scant & $3(10,3)$ & $4(12,9)$ & \multirow[t]{2}{*}{$1,000^{\mathrm{c}}$} \\
\hline Good & $(89,7)$ & $27(87,1)$ & \\
\hline \multicolumn{4}{|l|}{ Child educational level, n (\%) } \\
\hline Kindergarten & $2(6,9)$ & $2(6,5)$ & \multirow[t]{5}{*}{$0,981^{\circ}$} \\
\hline Primary school & $10(34,5)$ & $11(35,5)$ & \\
\hline Secondary school & $11(37,9)$ & $10(32,3)$ & \\
\hline Senior high school & $4(13,8)$ & $6(19,4)$ & \\
\hline College & $2(6,9)$ & $2(6,5)$ & \\
\hline \multicolumn{4}{|l|}{ Father educational level, $\mathrm{n}(\%)$} \\
\hline Senior high school & $5(17,2)$ & $7(22,6)$ & \multirow[t]{2}{*}{$0,605^{a}$} \\
\hline College & $24(82,8)$ & $24(77,4)$ & \\
\hline \multicolumn{4}{|l|}{ Mother educational level, n (\%) } \\
\hline Senior high school & $2(6,9)$ & $2(6,5)$ & \multirow[t]{2}{*}{$1,000^{\mathrm{e}}$} \\
\hline College & $27(93,1)$ & $29(93,5)$ & \\
\hline \multicolumn{4}{|l|}{ Father's occupation, $\mathrm{n}(\%)$} \\
\hline Private employee & $14(48,3)$ & $18(58,1)$ & \multirow[t]{5}{*}{$0,784^{\circ}$} \\
\hline Farmer & $2(6,9)$ & $1(3,2)$ & \\
\hline Government employee & $4(13,8)$ & $2(6,5)$ & \\
\hline Army/police & $1(3,4)$ & $2(6,5)$ & \\
\hline Enterpreneur & $8(27,6)$ & $8(25,8)$ & \\
\hline \multicolumn{4}{|l|}{ Mother's occupation, $\mathrm{n}(\%)$} \\
\hline Private employee & $8(27,6)$ & $14(45,2)$ & \multirow[t]{5}{*}{$0,366^{\circ}$} \\
\hline Farmer & $4(13,8)$ & $1(3,2)$ & \\
\hline Government employee & $7(24,1)$ & $4(12,9)$ & \\
\hline Enterpreneur & $6(20,7)$ & $7(22,6)$ & \\
\hline Housewife & $4(13,8)$ & $5(16,1)$ & \\
\hline \multicolumn{4}{|l|}{ Family history, n (\%) } \\
\hline Yes & $21(72,4)$ & $19(61,3)$ & \multirow[t]{2}{*}{$0,361^{\mathrm{a}}$} \\
\hline No & $8(27,6)$ & $12(38,7)$ & \\
\hline \multicolumn{4}{|l|}{ Clinical manifestation, $\mathrm{n}(\%)$} \\
\hline Nausea & 0 & $3(9,7)$ & $0,135^{a}$ \\
\hline Vomitus & $8(27,6)$ & $3(9,7)$ & \\
\hline Haematemesis & $5(17,2)$ & $7(22,6)$ & \\
\hline Abdominal pain & $16(55,2)$ & $18(58,1)$ & \\
\hline
\end{tabular}

Table 2. Subject Characteristic Study base on H. pylori infection 
The majority of the father's and mother's education level is college, both in two groups. There was no significant difference in education level, both in two groups $(p>0.05)$. We found private employees were the most between the two groups from father's and mother's occupation and there was no significant difference in the father and mother's type of work in the two study groups ( $p>0.05$ ). We also found $72,4 \%$ in the positive H. pylori group, and $61,3 \%$ in negative $H$. pylori had a previous family history with no significant difference analyzed with Chi-square $(\mathrm{p}=0.361)$. The most clinical manifestation of both two groups was abdominal pain, with $55,2 \%$ in the positive $H$. pylori group and $58,1 \%$ in the negative $H$. pylori group. There was no significant difference in clinical symptoms between the two groups with the Kruskal Wallis test $(\mathrm{p}=0.135)$. In the interleukin- 8 level, we found that the mean level of interleukin- 8 in positive H. Pylori was $25,86 \mathrm{pg} / \mu \mathrm{l}$ $(\mathrm{SD}=2.12 \mathrm{pg} / \mu \mathrm{l})$ and in negative $\mathrm{H}$. pylori was $10,99 \mathrm{pg} / \mu \mathrm{l}(\mathrm{SD}=2.26 \mathrm{pg} / \mu \mathrm{l})$. When we performed the Mann Whitney test, we found a significant difference in the mean levels of interleukin- 8 between the two groups with $\mathrm{p}<0.001$ (table 3 and figure 2).

\begin{tabular}{lccc}
\hline & \multicolumn{2}{c}{ H. pylori } & \multirow{2}{*}{$\mathbf{p}^{\mathbf{a}}$} \\
\cline { 2 - 3 } & $\boldsymbol{( + )} \mathbf{n = 2 9}$ & $(-) \mathbf{n}=\mathbf{3 1}$ & \\
\hline Interleukin 8, $p g / \mu l$ & & & \\
Mean & 25,86 & 10,99 & \\
Median & 16,61 & 10,41 & \\
SD & 29,34 & 3,99 & \\
Min - max & $10,05-128$ & $5,57-19,64$ & \\
Bann Whitney & & &
\end{tabular}

Table 3. Interleukin-8 level difference

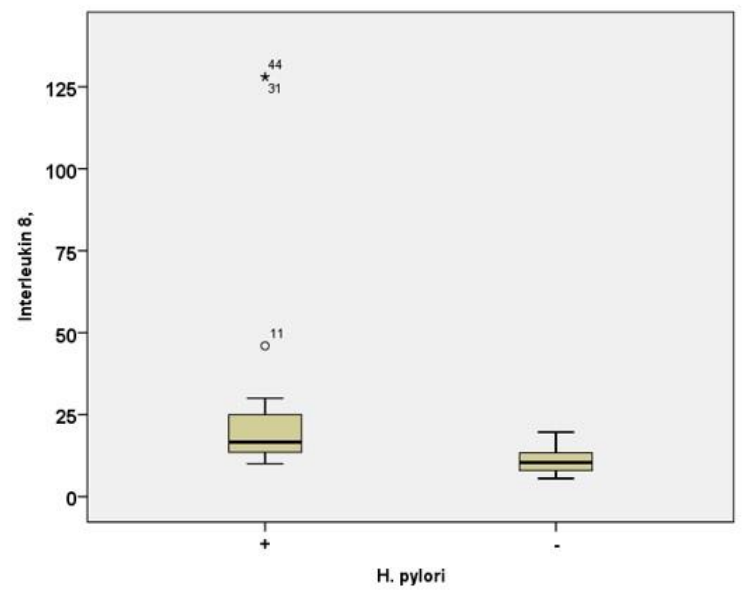

Figure 2. Boxplot of Interleukin-8 value

\section{Discussion}

H. Pylori are bacteria that cause gastritis, a microaerophilic bacteria, and live in a unique environment, under the mucus of the stomach wall, which is acidic, have the urease enzyme which can break down urea into ammonia that has alkaline nature, thus creating a microenvironment that allows these germs to survive..$^{1,2}$ Most people with gastritis might well recover, depending on how many factors are affected, but gastritis symptoms can recur at any time. In general, gastritis with minimal signs will respond well to the treatment given but in some cases, gastritis can become a serious case and can even become a life-threatening emergency. ${ }^{10}$ Diagnostic tests for $\mathrm{H}$. pylori infection are used to determine the presence of infection before administering treatment, to observe whether eradication has been achieved after antibiotics treatments and epidemiological studies, such as endoscopy and biopsy followed by histological examination, culture, urease 
test, and PCR, serology, HpSA or C-Urea Breath Test. ${ }^{2,11}$ The prevalence of H. pylori infection in developing countries is higher than in developed countries. The prevalence in developed countries is around 30-40\%, while in developing countries, it is $80-90 \%$. The prevalence of $\mathrm{H}$. pylori in adults and children in low to middle income countries and industrialized countries varies widely. ${ }^{12,13}$ Seroepidemiological studies in Indonesia show a prevalence of $36 \%$ to $46.1 \%$, with the youngest age is 5 months. In the young age group under 5 years, 5.3-15.4\% have been infected, and it is suspected that infection at an early age plays a role as a risk factor for malignant degeneration at a later age. ${ }^{14,15}$

Interleukin- 8 is an important factor that causes neutrophil influx to infected cells. Interleukin- 8 is a chemokine produced by monocytes, $\mathrm{T}$ lymphocytes, neutrophils, vascular endothelial cells, dermal fibroblasts, keratinocytes, hepatocytes, and human gastric cancer cells. In humans, interleukin-8 is encoded by the interleukin- 8 gene. Interleukin- 8 is chemotactic against T lymphocytes and basophils, and neutrophils in vitro. Also, Interleukin- 8 can induce neutrophils to release lysosome enzymes. Interleukin- 8 is undetectable in normal adult plasma. ${ }^{16}$ In vivo and in vitro studies have shown an increase in Interleukin- 8 levels associated with $\mathrm{H}$. pylori infection. The amount of Interleukin-8 expressed by gastric epithelial cells in response to $\mathrm{H}$. pylori is sufficient to induce neutrophil chemotaxis. ${ }^{17}$ In vivo and in vitro studies showed an increase in interleukin-8 levels associated with $\mathrm{H}$. pylori infection on which the induction of interleukin-8 expression was mediated through NF- $\mathrm{B}$ and protein activator-1 (AP-1). ${ }^{18,19} \mathrm{H}$. pylori will directly upregulate the expression of messenger RNA from Interleukin- 8 and Interleukin- 8 protein in epithelial cells. ${ }^{20-23}$

The H. pylori strain expresses three virulence factors. One of the most researched virulence factors is the CagA protein encoded by the cagA gene. Infection by strains that produce cagA is associated with higher production of interleukin-8 (IL-8) and a more severe degree of inflammation. ${ }^{23}$ Interleukin- 8 as a novel cytokine that activates neutrophils in patients infected with $\mathrm{H}$. pylori. Interleukin-8 is a potential mediator of the inflammatory response. As a potential chemotactic, Interleukin- 8 can activate polymorphonuclear leukocyte degranulation (PMN), respiratory burst and 5-lipooksigenase pathway, Interleukin-8 is produced by various immune and non-immune cells including monocytes / macrophages, endothelial cells, fibroblasts, hepatocytes and PMN. H. pylori strains containing cag-PAI (producing cag A) elicited a stronger interleukin8 response than those that did not. ${ }^{24}$ Several studies on the relationship between cagA status, gastric mucosal Interleukin-8 levels and the degree of mucosal inflammation have shown multiple results. Yamaoka et al. found severe level severity in positive $H$. pylori than in negative ones. PMN and MN infiltration was heavier in the cagA positive strain. Gaseous mucosal Interleukin-8 levels were associated with a significant degree of severity in the CagA positive strain. CagA positive was strongly related to high gastric mucosal Interleukin- 8 levels. MN cell infiltration was significantly correlated with IL-8 levels. ${ }^{25}$ Xuan et al. (2005) found higher levels of mucosal Interleukin-8 with the ELISA method in severe degrees of gastritis (neutrophil infiltration, mononuclear infiltration and atrophy). ${ }^{26}$ Andersen et al. found that interleukin- 8 and interleukin-10 were significantly elevated in the more severe degrees of inflammation and higher levels of H. pylori density. ${ }^{27}$ Holck et al. reported a significant association between Interleukin- 8 and Interleukin-10 with gastritis and $\mathrm{H}$. pylori density. The cytokines activity of interleukin- 8 and interleukin-10 is increased in patients infected with H. pylori. Interleukin-8 was found to be elevated in half of $\mathrm{H}$. pylori patients, compared with $25 \%$ in patients not infected with H. pylori. ${ }^{28}$

Reports from various countries around the world a decade after the bacteria discovery of $\mathrm{H}$. pylori states that H. pylori bacteria cause $95 \%$ of duodenal ulcers and $85 \%$ of gastric ulcers. H. pylori has been classified as a class 1 carcinogen in humans by the International Agency for Research on Cancer Consensus Group since 1994. Approximately $50 \%$ of the world's population is infected with H. pylori. ${ }^{29}$ Our study found that there is a difference in interleukin-8 levels between $\mathrm{H}$. pylori gastritis and non-H. pylori gastritis in children. 


\section{Conclusion}

The main cause of chronic gastritis is the infection of H. pylori, and interleukin- 8 is one of the important factors causing gastritis caused by $\mathrm{H}$. Pylori. There were no significant differences in the mean age of children, ethnicity, socioeconomics, education, family history, and symptoms in both groups positive $\mathrm{H}$. pylori and negative. There was a significant difference in the mean levels of interleukin-8 (IL-8) in children with positive H. pylori infection.

\section{Acknowledgements}

I would like to dedicate my gratitude to all the lecturers of Pediatric Department, Faculty of Medicine Universitas Sumatera Utara, my family, and my friends for their endless support.

\section{Conflicts of interest}

The author declares that there is no conflicts of interest.

\section{References}

1. Benjamin, et al. Helicobacter pylori Infection in children: Recommendation for Diagnosis and Treatment. Journal of Pediatrics Gastroentrology and Nutrition; 2008; 31:490-97.

2. Rajindrajith S, Devanarayana, NM, de Silva HJ. Helicobacter pylori infection in children. The Saudy Journal of Gastroenterology. 2009; 15:86-94

3. Fardah A, Ranuh RG, Atmadji SD. Infeksi helicobacter pylori pada anak. Kapita Selekta Ilmu Kesehatan Anak VI. FK Unair: Divisi Gastroenterologi Bagian Ilmu Kesehatan Anak. Surabaya. 2016

4. Lee KE, Khoi PN, Xia Y, Park JS, Joo YE, Kim KK, et al. Helicobacter pylori and interleukin-8 in gastric cancer. World $J$ Gastroenter. 2013;19(45):8192-202.

5. Farshad S, Rasouli, M., Jamshidzadeh A, Hosseinkhani A, Japoni A, Alborzi A, \& Ranjbar, R. (2010). IL-1ß (+ 3953 C/T) and IL-8 (-251 A/T) Gene Polymorphisms in H. pylori Mediated Gastric Disorders. Iranian Journal of Immunology, 7(2): 96-108.

6. Neto A. C, Rasmussen, L. T., de Labio, R. W, de Queiroz, V. F, de AC Smith, M, Viani, G. A, \& Payão, S. L. (2014). Gene polymorphism of interleukin 1 and 8 in chronic gastritis patients infected with Helicobacter pylori. Journal of Venomous Animals and Toxins including Tropical Diseases, 20(1), 17.

7. McColl KE. Clinical practice. Helicobacter pylori infection. N Engl J Med. 2010;362:1597-604.

8. Yeniova AO, Kucukazman M, Ata N, et al. Investigation of the association between mean platelet volume and Helicobacter pylori gastritis. Afr J Microbiol Res. 2013;7:2179-83.

9. Atharini, YH, Probosuseno, Nugroho, AE. Helicobacter Pylori Medical Pathways and Clinical Outcomes in Patients With Helicobacter Pylori. 2016;6(2):151-158.

10. Kotilea, K., Kalach, N., Homan, M., \& Bontems, P. (2018). Helicobacter pylori infection in pediatric patients: update on diagnosis and eradication strategies. Pediatric Drugs, 20(4), 337-351.

11. Hegar, B. Infeksi Helicobacter Pylori pada Anak.Sari Pediatri.2000;2: 82-89

12. Yang HR. Updates on the Diagnosis of Helicobacter pylori Infection in Children: What Are the Differences between Adults and Children? Pediatr Gastroenterol Hepatol Nutr. 2016;19(2):96-103.

13. Manfredi M, Gaiani F, Kayali S, Bizzarri B, Iuliano S, Minelli R, et al. How and when investigating and treating Helicobacter pylori infection in children. Acta Biomed. 2018;89(8-S):65-71.

14. Juffrie M, Soenarto SSY, Oswari H, Arief S, et al., Buku Ajar Gastroenterologi-Hepatologi. Jakarta: IDAI. 2010

15. Garna H, Nataprawira HM. Infeksi Helicobacter Pylori. Dalam Pedoman Diagnosis dan Terapi Ilmu Kesehatan Anak. Departemen/SMF Ilmu Kesehatan Anak Fakultas Kedokteran Universitas Padjajaran Dr. Hasan Sadikin. Bandung. 2015;(5): 315-6

16. Luster AD. Chemokines-chemotactic cytokines that mediate inflammation. N Engl J Med. 1998;338:436-45. 
17. Yamada H, Aihara T, Okabe S. Mechanism for Helicobacter pylori stimulation of interleukin-8 production in a gastric epithelial cell line (MKN 28): roles of mitogen-activated protein kinase and interleukin-1beta. Biochem Pharmacol. 2001;61:1595-604.

18. Banerjee A, Mukhopadhyay AK, Paul S, Bhattacharyya A and Swarnakar S. Unveiling the Intricacies of Helicobacter pyloriinduced Gastric Inflammation. In: Mozsik G, editor. Current Topics in Gastritis. Croatia: InTech Publishers; 2013. Chapter 7.

19. Wang X, Bai J, Shi D, Kang H. Association of IL-8 -251T/A, +781C/T and +396T/G genetic polymorphisms and haplotypes with breast cancer risk in a Northern Chinese population. Department of Thyroid and Breast Surgery, The Affiliated Hospital of Inner Mongolia Medical Collage, Hohhot, China. Int J Clin Exp Med 2018;11(12):13319-13328

20. Kim H, Lim JW, Kim KH. Helicobacter pylori-induced expression of interleukin-8 and cyclooxygenase-2 in AGS gastric epithelial cells: mediation by nuclear factor-kappaB. Scand J Gastroenterol. 2001;36:706-16.

21. Seo JH, Lim JW, Kim H, Kim KH. Helicobacter pylori in a Korean isolate activates mitogen-activated protein kinases, AP-1, and NF-kappaB and induces chemokine expression in gastric epithelial AGS cells. Lab Invest. 2004;84:49-62

22. Robinson K, Kenefeck R, Pidgeon E, Shakib S, Patel S, Polson R, et al. Helicobacter pylori-induced peptic ulcer disease is associated with inadequate regulatory T-cell responses. Gut. 2008;57:1375-85.

23. Rani HAA, Fauzi A. Infeksi Helicobacter pylori. In: Sudoyo AW, Setiyohadi B, editor. Buku Ajar Penyakit Dalam. 6th ed. Jakarta: Penyakit Dalam Fakultas Kedokteran Universitas Indonesia: 2014. p. 925-9

24. Montemurro P, Nishioka H, Dundon WG, de Bernard M, Del Giudice G, Rappuoli R, et al. The neutrophil-activating protein (HPNAP) of Helicobacter pylori is a potent stimulant of mast cells. Eur J Immunol. 2002;32:671-6.

25. Yamaoka Y, Kodama T, Kita M, Imanishi J, Kashima K, Graham DY. Relation between cytokines and Helicobacter pylori in gastric cancer. Helicobacter. 2001;6(2):116-24

26. Xuan J, Deguchi R, Yanagi H, Ozawa H, Urano T, Ogawa Y, et al. Relationship between gastric mucosal IL-8 levels and histological gastritis in patients with Helicobacter pylori infection. Tokai J Exp Clin Med: 2005; 30(2):83-8.

27. Andersen LP, Holck S, Janulaityte-Gu"nther D, Kupcinskas L, Kiudelis G, Jonaitis L, et al. Gastric inflammatory markers and interleukins in patients with functional dyspepsia, with and without Helicobacter pylori infection. FEMS Immunology and Medical Microbiology: 2005; 44:233-8.

28. Holck S, Norgaard A, Bennedsen M, Permin H, Norn S, Andersen LP, et al. Gastric mucosal cytokine responses in Helicobacter pylori-infected patients with gastritis and peptic ulcers. Association with inflammatory parameters and bacteria load. FEMS Immunology and Medical Microbiology. 2003;36:175-80.

29. Fiorini, Giulia, et al.(2013) "Culture-based selection therapy for patients who did not respond to previous treatment for Helicobacter pylori infection".Clinical Gastroenterology and Hepatology. 11.5: 507-510. 